\title{
CONTRAST-INDUCED NEPHROPATHY (REFERENCE REVIEW AND THE AUTHOR'S OWN FINDINGS)
}

\author{
M.T. Vatutin ${ }^{1,2}$, M.I. Zinkovych ${ }^{1}$
}

Abstract. This review shows the frequency of incidence of contrast-induced nephropathy in patients with ischemic heart disease who underwent percutaneous coronary intervention with intravascular administration of contrast media. The information about the pathogenesis, risk stratification and clinical manifestations of contrast-induced nephropathy is presented. Also, results of current completed studies about the possible therapeutic measures aimed at the prevention of this nephropathy are shown in this review.

Key words: kidney injury, contrast-induced nephropathy, contrast media, ischemic heart disease.

M. Gorky National Medical University (Donetsk) ${ }^{1}$ V.K. Gusak Institute of urgent and recovery surgery (Donetsk) ${ }^{2}$

Рецензент - проф. Л.О. Зуб

Buk. Med. Herald. - 2015. - Vol. 19, № 2 (74). - P. 220-225

Надійшла до редакції 11.03.2015 року

(c) Н.Т. Ватутин, М.И. Зинкович , 2015

УДК 615.457:615.454

\section{I.М. Довга \\ ВИКОРИСТАННЯ ДОПОМІЖНИХ РЕЧОВИН ДЛЯ ОЧНИХ ПРЕПАРАТІВ НА ГЕЛЕВІЙ ОСНОВІ (ОГЛЯД ЛІТЕРАТУРИ)}

Державна установа «Інститут мікробіології та імунології ім. І.І. Мечникова НАМН України», м. Харків

Резюме. У даному огляді надано перелік сучасних допоміжних речовин різного функціонального призначення, що використовуються при розробці очних препаратів на гелевій основі. Наведено вимоги щодо їх використання. Показано перспективність широкого застосування гелів в офтальмологічній практиці.
Лікарські форми (ЛФ) для офтальмології виділяються в особливу групу лікарських засобів у зв'язку з їх застосовуванням для найбільш чутливого біологічно та фізіологічно своєрідного органа - ока.

В офтальмологічній практиці застосовуються різні активні фармацевтичні субстанції - антибіотики, вітаміни, антикоагулянти, антисептики тощо. Перелічені активні інгредієнти вводять до складу різних очних ЛФ - крапель, мазей, гелів, плівок, суспензій, емульсій, таблеток тощо, в яких вони проявляють лікувальну або профілактичну дію та зручні для використання і зберігання.

На теперішній час в офтальмології широко застосовуються лікарські препарати у формі гелю, які дозволяють отримати ЛФ з оптимальною плинністю, що сприяє більш тривалому утриманню препарату на поверхні ока, пролонгації лікарських речовин. Пролонгація терапевтичного ефекту очних ЛФ є важливою проблемою, оскільки забезпечення більш тривалої дії при їх призначенні дозволяє скоротити кількість прийомів і тим самим створити умови, які б гарантували зменшення додаткового інфікування хворого ока $[17,29,30]$.

При розробці лікарського засобу у формі гелю, перш за все, необхідно враховувати загальні вимоги:
Ключові слова: допоміжні речовини, очні лікарські форми, гелева основа, синдром сухого ока.
- рівномірність розподілу лікарських речовин в основі;

- відсутність подразнюючої та сенсибілізувальної дії;

- індиферентність та стійкість основи;

- необхідні структурно-механічні властивості (рівномірність розподілу на поверхні, на яку вони наносяться; легкість видавлювання із первинної упаковки);

- стійкість до мікроорганізмів;

- стабільність при зберіганні;

- здатність виявляти відповідний терапевтичний ефект;

- необхідні споживчі характеристики - колір, запах, консистенція тощо.

Разом із загальними вимогами до очних гелів враховують ряд додаткових вимог, що пояснюється способом їх використання:

- лікарські речовини, які нерозчинні в гелевій основі, повинні бути подрібнені до мінімального розміру часток, щоб запобігти пошкодженню слизової оболонки ока;

- витримувати режими термічної обробки;

- мати відповідну ізотонічність;

- мати необхідний та стабільний рівень $\mathrm{pH}$ середовища $[10,13]$. 
3 урахуванням вищевикладеного, важливим етапом при фармацевтичній розробці очних гелів $\epsilon$ вибір оптимальної композиції допоміжних речовин для забезпечення необхідного терапевтичного ефекту препарату, стабільного в процесі зберігання.

Створення ефективних лікарських препаратів у формі очних гелів потребує застосування великої кількості допоміжних речовин. До недавнього часу до допоміжних речовин висували вимоги фармакологічної та хімічної індиферентності. Однак ці речовини можуть значно впливати на фармакологічну активність лікарських речовин: посилювати або знижувати дію активних інгредієнтів, змінювати характер дії під впливом різних причин, а саме - комплексоутворення, молекулярні реакції, інтерференції тощо [29, 30].

До допоміжних речовин повинні висуватися такі вимоги:

- забезпечення прояву відповідної фармакологічної дії лікарського засобу 3 урахуванням його фармакокінетики відповідно до медичного призначення препарату;

- біологічна нешкідливість та біосумісність 3 тканинами ока;

- відповідність формоутворюючих властивостей лікарської форми (допоміжні речовини повинні надавати лікарській формі відповідні властивості: фізико- хімічні та структурно-механічні);

- не повинні виявляти негативного впливу на органолептичні властивості препарату: запах, колір тощо;

- відсутність хімічної або фізико-хімічної взаємодії з лікарськими речовинами, пакувальними матеріалами, а також матеріалами технологічного обладнання в процесі виготовлення лікарських препаратів та при їх зберіганні;

- відповідність вимогам максимально припустимої мікробної контамінації;

- витримувати режими стерилізації;

- бути економічно доступними $[10,13,30]$.

Номенклатура допоміжних речовин, які використовуються в технології очних гелів, численна. При виготовленні очних гелів використовують допоміжні речовини різні за природою, хімічною структурою та функціональним призначенням [23].

Як основа для гелів використовують високомолекулярні сполуки (ВМС) природного та синтетичного походження з М. м $\geq 10000$. Їх молекули представляють собою довгі нитки, що переплітаються між собою або звернуті в клубки, які в розчині утворюють гелеві структури. ВМС використовуються також як стабілізатори пролонгуючих компонентів, адгезивних засобів [3].

У фармакопеях різних країн представлений цілий ряд гелеутворювачів: альгінова кислота та iii солі, бентоніти, пектини, желатини, похідні целюлози, полімери та сополімери вінілацетату, полімери оксіетилену, карбомери [10, 34, 35].

Природні речовини - кислота альгінова та іiі солі (альгінати), агароїд, пектинові речовини, аубазидан, колаген, желатин, желатоза та бентоніти мають високі емульгувальні та плівкотвірні властивості, забезпечують лікарським препаратам м'якість, дисперсність, високі адсорбційні властивості, легку віддачу лікарських речовин та відрізняються від синтетичних речовин високою біологічною безпекою. Однак, незважаючи на перелічені вище властивості, вони мають ряд недоліків - перш за все, схильність до мікробної контамінації $[8,11]$.

Найбільш практичне використання як гелеутворювачі знаходять синтетичні та напівсинтетичні речовини - метилцелюлоза розчинна, натрій карбоксиметилцелюлоза, оксипропілметилцелюлоза, ацетилцелюлоза, гідроксипропілметилцелюлоза, полівінол, полівінілпіролідон. У технології їх розчини використовують як згущувачі, стабілізатори, емульгатори та пролонгуючі компоненти [8, 11].

У світовій фармацевтичній практиці для виготовлення гелів найбільш широко застосовують крос-сополімери поліакрилової кислоти - карбомери. Карбомери утворюють стійкі гелеві структури при незначних концентраціях гелеутворювачів від $0,05 \%$ до 5,0 \% та виявляють високу згущвальну здатність у широкому діапазоні $\mathrm{pH}$ 5-9 [7, $16,20-22]$.

Використання ВМС у технології ЛФ грунтується також і на їх поверхнево-активних властивостях. Залежно від хімічної структури розрізняють три типи поверхнево-активних речовин (ПАР): катіонні, аніонні, неіоногенні. Усі типи ПАР у тому або іншому ступені використовуються у фармацевтичній технології як гідрофілізатори, солюбілізатори, емульгатори, стабілізатори тощо.

Найбільше використання в останній час знаходять неіоногенні ПАР. Цю групу складають оксіетильовані похідні ряду органічних сполук, моноефіри сахарози, гліцериди, ВМС жирних кислот, ефіри жирних кислот та багатоатомних спиртів і їх оксіетильовані похідні, які називаються спенами, твінами тощо.

ПАР, змінюючи фізико-хімічні властивості лікарської форми, можуть помітно впливати на терапевтичну ефективність лікарських препаратів. Низькі концентрації ПАР можуть збільшувати всмоктування деяких активних фармацевтичних субстанцій (сульфаніламіди, барбітурати, деякі ефіри кислоти саліцилової, гідрокортизон). Високі концентрації багатьох ПАР знижують резорбцію лікарських речовин із розчинів $[1,8$, $13,32]$.

Зволожуючі агенти при розробці очних гелів можуть виявляти різнобічні функції. Їх уводять до складу основи з метою розчинення лікарських речовин, швидкого та рівномірного розподілу на поверхні ока, як пом'якшувальні, вологозатримувальні, структуроутворювальні речовини пенетраторів та солюбілізаторів. До них відносяться гідрофільні неводні розчинники: пропіленгліколь, макроголи 200-600, гліцерин, маніт, сорбіт тощо $[23,33]$. 
Для досягнення максимального терапевтичного ефекту препарату та стабільності його компонентів велике значення має $\mathrm{pH}$ гелю. Для слизової рідини ока нормальним є рН 7,0-7,4. Діапазон комфорту ока знаходиться в більш широких межах $\mathrm{pH}$ 6,6-7,8. Стабільність $\mathrm{pH}$ у заданому діапазоні дозволяє забезпечити ефективність препарату, продовжити термін його придатності, запобігти хімічному подразненню очей. На показник $\mathrm{pH}$ препарату можуть впливати фактори навколишнього середовища. Для підтримання стабільного рН-рівня препарату використовують буфери у вигляді розчинів - борну кислоту, борат натрію, перборат натрію, цитрати, фосфати, лимонну кислоту $[11,30]$.

Отримання гелевих систем 3 оптимальним значенням $\mathrm{pH}$ та рівнем в'язкості на основі карбомерів досягається додаванням нейтралізуючих агентів - лугів різної хімічної природи: натрію та калію гідроксиду, триетаноламіну, трометамолу. Неорганічні луги можуть призвести до сильної перенейтралізації системи. Використання амінових нейтралізаторів забезпечує більш ефективне керування значеннями концентрації водневих іонів, однак вони токсичні та в ряді випадків можуть викликати алергічні реакції. Трометамол на відміну від триетаноламіну нетоксичний $[7,18,26]$.

Комфортність очних препаратів при застосуванні забезпечується концентрацією іонів водню та осмотичним тиском (ізотонічністю), значення яких повинні бути аналогічними відповідним показникам сльозової рідини або знаходитися в діапазоні значень, що забезпечують комфортність. У випадку відхилень ізотонічність офтальмологічних препаратів досягається додаванням визначених кількостей натрію хлориду, натрію сульфату або натрію нітрату, калію хлориду, маніту, гліцерину, глюкози тощо $[15,30]$.

Вирішення проблем, пов'язаних із запобіганням мікробної забрудненості та комфортності офтальмологічних лікарських засобів, має особливу актуальність, оскільки ці ліки є системою зі значним обсягом рідкої фази порівняно з вмістом діючих речовин та в ряді випадків містять компоненти, які є живильним середовищем для мікроорганізмів.

У практиці виготовлення очних препаратів має значення не тільки асептика, а також і використання консервантів, метою яких є запобігання розповсюдження мікроорганізмів у лікарській формі.

Найчастіше в офтальмологічних препаратах використовують наступні консерванти - бензалконію хлорид, декаметоксин, цетримід, поліквад, хлорбутанол, хлоргексидину біглюконат, полігексанід, алексидин, тіомерсал, метилпарагідроксибензоат та пропілпарагідроксибензоат. Консервантам притаманна токсична дія, що визначає необхідність їх ретельного вибору [9, 25, 31].

Етилендіамінтетраоцтова кислота (ЕДТА) не $€$ консервантом та вводиться до складу гелів для посилення дії наявних у них консервантів та дезінфекційних речовин [25, 31].

Мета використання очних гелів може бути різною - лікування опіків, виразок, дефектів епітелію, порушень трофіки та дистрофії рогівки, синдрому сухого ока тощо.

На теперішній час значною проблемою в офтальмології є лікування синдрому сухого ока. Синдром сухого ока - це стан, який характеризується неадекватним зволоженням рогівки та кон'юнктиви. Він може бути самостійною патологією або одним із основних проявів певних захворювань. Зайва сльозоточивість проявляється в тих випадках, коли причиною синдрому сухого ока $\epsilon$ не абсолютна недостатність сльозової рідини, а порушення її якісного складу. Сльози захищають очі від висихання, мікробів, впливу пилу тощо. Баланс змочування-висихання може порушити багато причин: велике навантаження на очі при роботі за комп'ютером, куріння, забрудненість повітря, використання контактних лінз, недостатність вітамінів, реакція на деякі медикаменти тощо. Сприяють появі цього синдрому також хронічний кон'юнктивіт (алергічний, хламідіозний) та хвороба Шегрена. У результаті сльозова плівка, яка вкриває поверхню очей, встигає висохнути до того часу, як повіки, блимнувши, знов зволожать очне яблуко [6, 12].

Для лікування синдрому сухого ока застосовуються різні консервативні засоби лікування, у тому числі пролонговані сльозозамінники на гелевій основі, механізм дії яких заключається у формуванні на поверхні рогівки стійкої сльозової плівки. Так діє препарат Офтагель (Франція), який представляє собою нелінійний полімер акрилової кислоти, що має здатність взаємодіяти 3 муцином на епітелії рогівки. Це сприяє формуванню стійкої потовщеної сльозової плівки на тривалий час [19].

Очний гель Відисик (Німеччина) підходить для лікування усіх проявів синдрому "сухого ока". Відисик має відмінні тиксотропні властивості - при кожному змиканні повік препарат переходить у рідку фазу, а потім знову структурується в гель. Препарат тривало утримує рідину на поверхні ока. Це забезпечує збільшену в'язкість гелю, який довше за будь-яку іншу рідину зберігається на поверхні очного яблука. Гель створено на основі трьох полімерів акрилової кислоти, кожен 3 яких має різну розчинність у воді, що дозволяе максимально наближено відтворювати сльозову рідину [27].

При прогресуванні хвороби часто виникає пошкодження слизової оболонки ока. У таких випадках раціональніше використовувати препарат, який поряд із зволоженням буде покращувати регенерацію епітеліальних клітин. Таким препаратом є Корнерегель (Німеччина) [24].

На теперішній час на ринку України вітчизняні аналоги штучних сліз відсутні. Поява відносно недорогих ліків допомогла б вирішити про- 
блему зниження вартості лікування синдрому сухого ока.

Спеціально для лікування хронічних блефаритів, які є причиною розвитку різних очних захворювань (кон'юнктивіт, ячмінь, крайовий кератит), розроблено препарати на гелевій основі Блефарогель-1 та Блефарогель-2 (Росія). Обидва гелі, що створені на основі гіалуронової кислоти, мають м'яку та ніжну консистенцію та не призводять до подразнення й алергічних реакцій. Одним із компонентів, що входить до складу Блефарогелю-2, є сірка, яка очищує вивідні протоки залоз на краях повік і нормалізує їх секрецію. При застосуванні препарату сірка перетворюєтья в сульфіди та пентатіонову кислоту, які виявляють протимікробну та протипаразитарну дію $[4,5]$.

При глаукомі, а також для покращання трофіки при тромбозі центральної вени сітківки та атрофії зорового нерва, використовують гель пілокарпіну на основі карбополу 940 [14].

Як антисептичний та антизапальний засоби в офтальмології застосовують очний комплекс гель на основі екстракту календули. Також розповсюджений контактний гель Олігель (Росія), що відповідає світовим стандартам, зокрема, таким закордонним аналогам у формі очних гелів як Солкосерил (Швейцарія), Лакрисин (Чехія) та Актовегін (Австрія), які застосовують при використанні контактних лінз [17].

Гель із полігуанідину фосфатом для лікування інфекційних захворювань ока створено на основі полівінілового спирту та метилцелюлози. Ізоосмотичність гелю забезпечуться боратним буфером та натрію хлоридом. Для збільшення та збереження прозорості гелю до його складу введено колідон [2].

Вітчизняним виробником ВАТ «Фармак» розроблено технологію і якісний склад очних крапель на основі нетоксичного гідрофільного полімеру, який за своїм вмістом дозволяє забезпечити створення стабільної плівки на поверхні ока. Для запобігання пошкодженню епітелію в складі ЛФ використовують протектори рогівки декспантенол або таурин. У препараті також використовується буферна система, яка створює оптимальне значення $\mathrm{pH}$. Мікробіологічну чистоту після відкриття первинної упаковки забезпечує малотоксичний консервант. Розроблений спосіб отримання препарату, який включає метод стерильної фільтрації в'язкого розчину, зменшує кількість операцій та забезпечує стерильність препарату [28].

\section{Висновки}

1. Проведений аналіз даних літератури показав, що очні препарати на гелевій основі $\epsilon$ перспективною лікарською формою для застосування в офтальмології. При розробці очних гелів використовується велика кількість допоміжних речовин різного функціонального призначення.

2. Важливим етапом при фармацевтичній розробці очних гелів $є$ науково обгрунтований вибір оптимальної композиції допоміжних речовин для забезпечення необхідного терапевтичного ефекту препарату, стабільного в процесі зберігання.

\section{Література}

1. Абрамзон А.А. Поверхностно-активные вещества: синтез, анализ, свойства, применение / А.А. Абрамзон, Л.П. Зайченко, С.И. Файнгольд. - Л.: Химия, 1988. C. $160-200$.

2. Абрикосова Ю.Е. Разработка и исследование офтальмологических лекарственных форм с антисептиками гуанидинового ряда: дис. на соискание науч.степ. кандидата фарм. наук: 15.00 .01 / Абрикосова Юлия Евгеньевна. - М., 2005. - 186 с.

3. Алюшин М.Т. Современное состояние научних исследований по применению полимеров в фармации / М.T. Алюшин, И.О. Грицаенко, М.В. Каменская // Синтетические и биологические полимеры в фармации: Сборник научных трудов ВНИИФ. - М., 1990. - Т. 28. C. 5-11.

4. Блефарогели в комплексном лечении блефароконъюнктивитов и синдрома «сухого глаза» [Электронный ресурс] / Г.С. Полунин, Т.Н. Сафонова, А.А. Федоров [и др.] // РМЖ. - 2004. - №1. - Режим доступа к журн.: http://www.rmj.ru/articles_4927.htm

5. Блефарогелі в профілактиці та лікуванні блефаритів, блефарокон'юнктивітів і демодекозу / Г.С. Полунін, В.В. Куренков, Е.А. Каспарова [та ін.] // Окуліст. 2003. - № 9. - С. 13.

6. Бржеский В.В. Синдром "сухого глаза": современные аспекты диагностики и лечения / В.В. Бржеский, Е.Е. Сомов // Синдром сухого глаза. - 2002. - № 1. - С. 3-9.

7. Воловик Н.В. Розробка гелевих основ з карбомерами для м'яких лікарських засобів / Н.В. Воловик, М.О. Ляпунов // Вісн. фармації. - 2001. - № 3 (27). C. 51 .

8. Глузман М.Х. Поверхностно-активные вещества и их применение в фармации / М.Х. Глузман, Г.С. Башура, Г.В. Цагареишвили. - Тбилиси: Мецниераба, 1972. $202 \mathrm{c}$.

9. Гудзь О.В. Итоги и перспективы клинического применения дезинфекционных средств из группы четвертичных аммониевых соединений / О.В. Гудзь // Прови3ор. - 1998. - № 12. - С. 46-48.

10. Державна Фармакопея України / Державне підприємство "науково-експертний фармакопейний центр. - 1-е вид. - Х.: РІРЕГ, 2001. - $556 \mathrm{c.}$

11. Допоміжні речовини та їх застосування в технології лікарських форм. Довідковий посібник / Ф. Жогло, В. Возняк, В .Ф. Попович [та ін]. - Львів: Центр Європи, 1996. -95 с.

12. Дослідження сльозової рідини в нормі та при зниженні сльозопродукції у хворих на хворобу Шегрена та синдром Шегрена / Р.П. Морозова, Г.Д. Жабоєдов, В.В. Кіреєв [та ін.] // Укр. біохім. ж. - 1996. - Т. 68 , № 2. - C. 82-87.

13. Дранік Л.І. М'які лікарські форми та допоміжні речовини для їхнього виробництва / Л.І. Дранік // Фармац. ж. -1990 . - № 3. - С. 45-47.

14. Егоров Е.А. Современные аспекты гипотензивного лечения глаукомы [Электронный ресурс] / Е.А. Егоров, Т.В. Ставицкая // РМЖ. - 2000. - №1. - Режим доступа к журн.: http://www.rmj.ru/articles 1513.htm

15. К вопросу созданию глазных капель на основе экстракта алоэ / Л.Н. Андрюкова, В.П. Георгиевский, К.В. Курищук [и др.] // Фармаком. - 2005. - № 4. C. $87-92$.

16. Козир Г.Р. Вивчення осмотичних властивостей гелів на основі карбополу / Г.Р. Козир, О.І. Тихонов, Н.В. Живора // Фармація XXI століття: всеукр. науково-практична конф., 23-24 жовтня 2002 р.: тези допов. - X., 2002. - C. 46-47. 
17. Компендиум 2010 - лекарственные препараты / Под ред. В.Н. Коваленко, А П. Викторова. - К: МОРИОН, 2010. - $2240 \mathrm{c}$.

18. Ляпунов Н.А. Создание мягких лекарственных средств на различных основах. Сообщение 2. Исследование реологических свойств гелей, образованых карбомерами / Н.А. Ляпунов, Н.В. Воловик // Фармаком. - 2001. - № 2. - С. 52-61.

19. Майчук Ю.Ф. Препарат искусственной слезы Офтагель в лечении синдрома сухого глаза после эпидемического кератоконъюнктивита [Электронный ресурс] / Ю.Ф. Майчук, Е.В. Яни, Д.Ю. Майчук // РМЖ. 2001. - T. 2, №4. - Режим доступа к журн.: http:// www.rmj.ru/articles_4729.htm

20. Обгрунтування введення біолоічно активних речовин у гідрогелеві основи 3 карбомером / О.Г. Башура, I.I. Баранова, Ю.В. Ковтун [та ін.] // Вісн. фармації. 2004. - № 3 (39). - С. 45-48.

21. Осмотически активные лекарственные гели для лечения воспалительных процессов / И.М. Перцев, Б.М. Даценко, Д.И. Дмитриевский [и др.] // Технологические аспекты создания лекарственных форм: Науч. тр. - М., 1986. - Т. 24. - С. 94-98.

22. Перспективи використання карбополів у технології косметичних i лікарських гелів / О.Г. Башура, Є.В. Гладух, I.I. Баранова [та ін.] // Вісн. фармації. 1999. - № 2. - С. 73-75.

23. Полимеры в фармации / Под ред. А.И. Тенцовой, М.Т. Алюшиной. - М., Медицина, 1985. - 256 с.

24. Рыбакова Е.Г. Корнерегель - новый стимулятор репаративной регенерации [Электронный ресурс] / Е.Г. Рыбакова, Г.Б. Егорова, Н.И. Калинич // РМЖ. 2001. - №4. - Режим доступа к журн.: http:// www.rmj.ru/articles_4724.htm

25. Сергиенко Н.М. Микробиологический аспект применения контактных линз / Н.М. Сергиенко, В.П. Кова- льчук, С.А. Рыков // Офтальмол. ж. - 1993. - № 2. С. $112-115$.

26. Сиденко Л.Н. Исследование по выбору вспомогательных веществ для создания стабильных глазных/ назальных капель на основе экстракта биологически активных веществ животного происхождения / Л.Н. Сиденко // Фармаком. - 2005. - № 4. - С. 78-82.

27. Слонимський Ю.Б. Применение препарата видисик в лечении синдрома "сухого глаза" / Ю.Б. Слонимський, Г.М. Черпакова, Ю.М. Корецкая // Синдром сухого глаза. - 2002. - № 1. - С. 15-16.

28. Сяркевич O.P. Очні краплі для профілактики синдрому "сухе око" / О.Р. Сяркевич, М.I. Борщевська, Є.М. Круглов // Сьогодення та майбутнє фармації: Всеукраїнський конгрес, 16-19 квітня 2008 р.: тези допов. - Х., 2008. - С. 430.

29. Технология и стандартизация лекарств: Сб. науч. тр. Т. 1 . - Х.: ИГ «РИРЕГ», 1996. - 784 с.

30. Технология и стандартизация лекарств: Сб. науч. тр. Т. 2 . - Х.: ИГ «РИРЕГ», 2000. - С. 678-697.

31. Фетисова Е. Г. Изучение совместимости кромгликата натрия и бензалкония хлорида в водных растворах этап фармацевтической разработки глазных капель антиаллергического действия / Е.Г. Фетисова, Л.Н. Андрюкова, Е.С. Назарова // Фармаком. - 2007. № 4. - С. 56-62.

32. Цагареишвили Г. В. Консистентные свойства мягких лекарственных средств и методы их применения / Г.В. Цагареишвили, Г.С. Башура. - Тбилиси: Мецниереба, 1969. - $97 \mathrm{c}$.

33. Шварц Р. Увлажняющие средства / Р. Шварц, И. Томас // Косметика и медицина. - 2002. - № 3. C. 27-33.

34. Carbomers // European Pharmacopeia, 2000. P. 488-489.

35. European Pharmacopeia. $4^{\text {th }}$ ed. - Strasburg: Council of Europe, 2001. -2416 p.

\section{ИСПОЛЬЗОВАНИЕ ВСПОМОГАТЕЛЬНЫХ ВЕЩЕСТВ ДЛЯ ГЛАЗНЫХ ПРЕПАРАТОВ НА ГЕЛЕВОЙ ОСНОВЕ (ОБЗОР ЛИТЕРАТУРЫ)}

\section{И.Н. Долгая}

Резюме. В данном обзоре представлен перечень современных вспомогательных веществ различного функционального назначения, которые используются при разработке глазных препаратов на гелевой основе. Приведены требования относительно их использования. Показана перспективность широкого применения гелей в офтальмологической практике.

Ключевые слова: вспомогательные вещества, глазные лекарственные формы, гелевая основа, синдром сухого глаза.

\section{THE USE OF ADJUVANTS IN GEL BASED OPHTHALMIC MEDICATIONS (REFERENCE REVIEW)}

\section{I.N. Dovha}

Abctract. The list of modern subsidiary materials of different functionality, which are used in the development of gel based ophthalmic drugs, is provided in this review. The requirements for their usage are presented. The prospects of wide application of gels in ophthalmic practice are shown.

Key words: adjuvants, ophthalmic dosage forms, gel base, dry eye syndrome.

State Establishment "I.I. Mechnikov Institute of Microbiology and Immunology of NAMS of Ukraine (Kharkiv)

Рецензенти: проф. Я.І. Пенішкевич

доц. О.В. Геруш
Buk. Med. Herald. - 2015. - Vol. 19, № 2 (74). - P. 225-229

Надійшла до редакції 27.02.2015 року

(C) I.M. Довга, 2015 